\title{
Prototype SOVA Development: Aircraft Lyfe Cycle Extension
}

\author{
Vanja Stefanović ${ }^{1)}$ \\ Marija Blažićc ${ }^{1)}$ \\ Marina Ostojić ${ }^{2)}$ \\ Tonko Mihovilovic ${ }^{2)}$ \\ Dragan Ilic $^{3)}$
}

\begin{abstract}
With the aim of a new aircraft development, single engine four-seater aircraft with fixed landing gear, analysis of the existing structure has been conducted. Analysed subject was earlier produced UTVA 75 structure, which has been used as the basis of the new aircraft prototype. Elements of the structure were tested with different Non-Destructive Testing (NDT) methods. This paper describes condition of existing structure and its test results, as well as necessary repairs and replacement of the damaged parts, in order to extend life cycle of the structure.
\end{abstract}

Key words: propeller aircraft, light aircraft, aircraft structure, testing method, non destructive testing, lifecycle, life cycle extension.

\section{Introduction}

$\mathrm{M}$ AKING a general purpose airplane, suitable for any purchaser or any use, is impossibile. However, it is often possible to arrange a design which would simplify the future changes without sacrificing either structural or aerodynamic efficiency or taking a weight penalty [1]. The design process must not only address interactions between traditional aerospace disciplines (e.g. aerodynamics, structures, controls, propulsion), but should also account for "life cycle" disciplines (e.g. economics, reliability, manufacturability, safety, supportability, etc.). These disciplines can bring a variety of uncertainties of differing natures to the design problem, especially when innovation occurs within and amongst the disciplines [2]. In a process of upgrading an existing one, some of the traditional aerospace disciplines are less reviewed, due to the already defined aerodynamic with the current structure. Nevertheless controls and propulsion are often revised, to follow requirements of the customers and to be concurrent on the market. When it comes to "life cycle" disciplines in a process of upgrading, they should be considered completely from the start (e.g. manufacturability of the prototype and possible serial production component supportability, etc.) and then decision should be made whether the new product is affordable or not.

With fruitful tradition of designing and manufacturing metal structure aircrafts (Galeb G-2, Supergaleb G-4, Utva 75, Lasta and now Sova), mostly for training military pilots, Serbia has vast amount of experienced experts of all generations, who can deal with new challenges in this area. Aircrafts were designed and produced for our needs and also numerous were sold to foreign countries. Positive feedback from customers all around the world, and fact that many aircrafts are still in operational use, confirms our production capabilities and proficient design approach to different type of aircrafts. In a case of Utva 75 aircraft (Fig.1), 140 were produced and plenty are still in use.

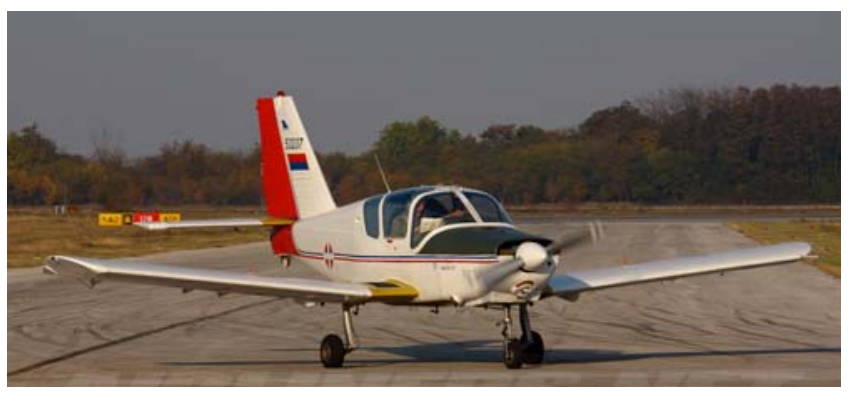

Figire 1. Utva 75 aircraft

All metal Utva 75 aircraft, certified according to FAR 23, is side-by-side seating configuration with an advantage that pilot and instructor can see each other's actions. With the conversion in four-seater aircraft, future generation pilots will be able, since being in the back seats during the flight, to learn from the instructor and pilot by watching. Special advantage of this aircraft version (four-seater Sova), which can be used for the initial training of several trainees, is considerably reducing the cost of the training. That is the reason why nowadays popularity of the four-seater trainer is increased all around the world.

With the aim of Utva 75 aircraft conversion into four-seater aircraft Sova (Utva 75 A41M), process of creating prototype and modification of the existing structure is shown in this paper.

\footnotetext{
Military Technical Institute (VTI), Ratka Resanovića 1, 11132 Belgrade, SERBIA

2) DOO UTVA AI, Jabučki put 2, 26000 Pančevo, SERBIA

3) Jugoimport SDPR, Bulevar umetnosti 2,11150 New Belgrade, SERBIA

Correspondence to: Vanja Stefanović; e-mail: vanja_stef@yahoo.com
} 


\section{Structure life-cycle extension}

Nowadays conversion of the aircraft, with upgraded avionics and other systems, is the most economical approach and frequently applied solution. Whether it is a case of business jet conversion to military trainer [3], as it was in The United States Navy, or it was a decision of an aircraft conversion within an air force with more limited budget, it is money-time saving solution without loss of efficiency.

With some past experience of Utva 75 conversion in fourseater aircraft, the feasibility study started and conclusion was made. Utva 75 structure meets the performance goals of a new aircraft with some changes in the cockpit area, upgraded avionics and with redesign of propulsion and controls, prototype could be finalized shortly. The decision that the prototype is going to be conversion of the Utva 75 off-theshelf structure was made, and it is presented in Fig.2.

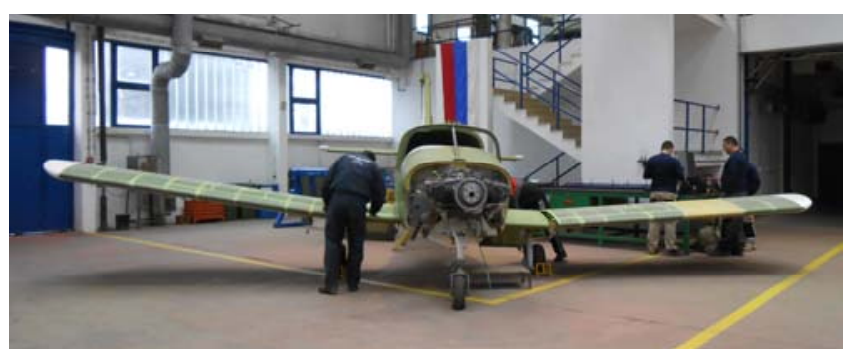

Figure 2. Future prototype structure

In our case, UTVA Aircraft Industry has main responsibility for the design and production of the all necessary parts and has to ensure that the project finishes on time. Military Technical Institute and RD Diagnostics d.o.o. were engaged in a process of examining existing structure and a possible life cycle extension.

\section{Non Destructive Testing Methods}

Non Destructive Testing methods (NDT) are widely used technics to probe structures and materials either before they enter use, or as a part of maintenance program. Whether the aim is to observe microstructures of the welds, measure the thickness of material or detect induced cracks in a material NDT methods are appropriate choice for fast and efficient inspection. NDT is now compulsory for many aerospace firms and is a vital part of the production process.

NDT methods were used in a process of examining structure for life-cycle extension. All parts of the structure planned to be perserved, and especially vital ones, were subject of inspection with different methods, performed by the firm $R D$ Diagnostics and approved by Military Technical Institute. Following NDT methods were used in a process of testing structure.

- Visual inspection(VT) is probably the most widely used of all the nondestructive tests. VT was conducted on all parts, using tools: a magnifying glass zoom $5 \mathrm{x}$ and endoscope. Magnifying glass was used to estimate the depth of corrosion in places where it was discovered.

- Endoscope (ES) was used for testing of all inaccessible places, the inner surfaces of the wings and the fitting interior, the inner surfaces of the fuel tank, fins, flaps, elevator and rudder, in order to detect hidden defects and corrosion.

- Penetrant test (PT) has its fundamental purpose of increasing the visibility contrast between a discontinuity and its background. It was carried out on some fuselage fittings and pedals in order to detect surface defect and cracks.
- Edy Curent Test (ECT) is well suited for the detection of the service induced cracks usually caused either by fatigue, or by stress corrosion. Inspection can be used with minimum preparation of parts and a high degree of sensitivity. ECT was performed on all connections that are not going to be replaced. That includes connections of wing and fuselage structure e.g. rivets, bolts, the connection of all fittings and connections of vertical and horizontal stabilizers. All magnetic parts are also included, in order to detect cracks and surface defects.

- Ultrasonic test (UT) permits the detection of small flaws, with single surface accessibility only, and it is capable of estimating the location and size of the defect and can also be used for thickness measurements, where only one surface is accessible. UT was performed on the chosen rivets, especially those which connect fittings with the rest of the structure, axles and joints in order to determine defect of homogeneity.

Every element that has been inspected was firstly detached from the rest of the structure, if that was possible, and then cleaned and prepared for testing.

\section{Structure testing}

The aircraft chosen to be a prototype was made of main assemblies of already produced Utva 75, whole metal structure. Wing, horizontal and vertical stabilizer were in storage and were never used, with an exeption of the fuselage, the elevator and the rudder that were in use for short period of time. The testing was conducted in the facilities of the UTVA $A I$ with a help of a factory personnel. They performed first measures by checking the geometry of the aircraft. Structure testing was next step of the extending life-cycle process. In Fig. 3 is shown fuselage of Utva 75 aircraft.

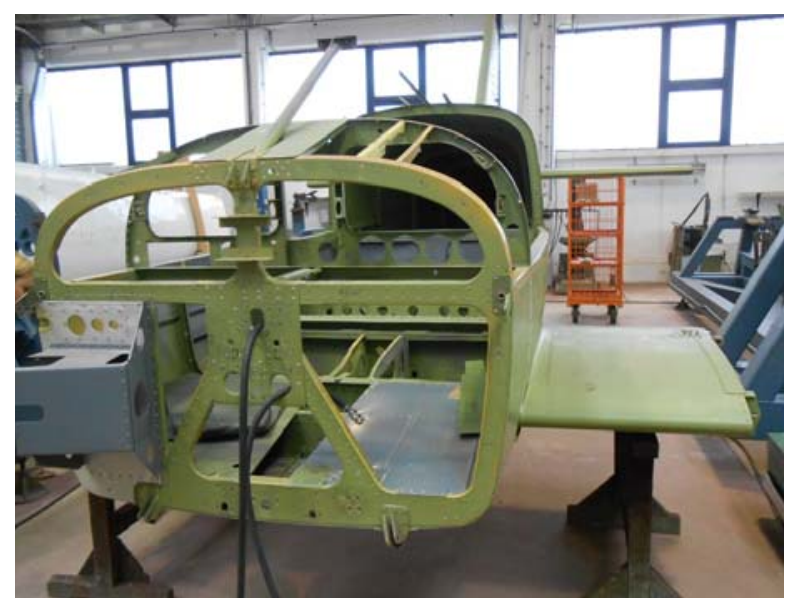

Figure 3. Fuselage in the UTVA AI facilities

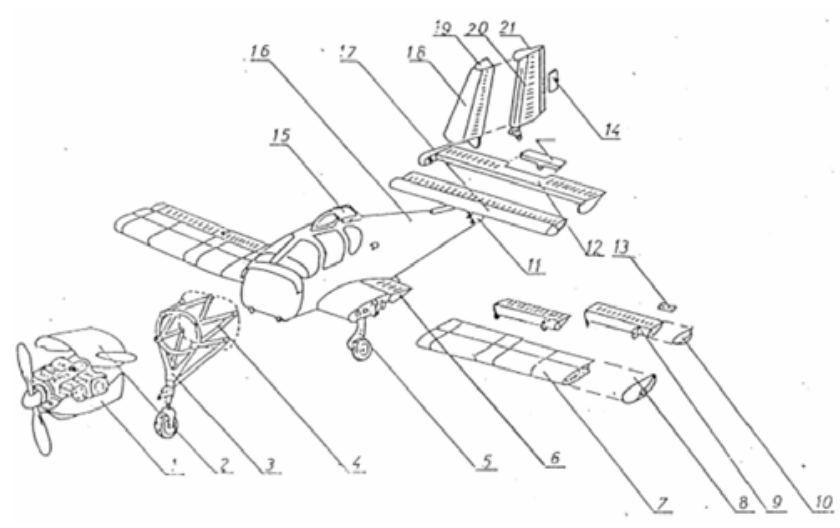

Figure 4. Main examined structural elements and assemblies 
As mentioned earlier, Military Technical Institute and $R D$ Diagnostics d.o.o. started inspection according to already formed plan. In this plan main structural elements, one by one, anticipated as subjects of the analysis. The structure was tested with different NDT methods.

In Fig.4 main structural assemblies of the examined structure are presented (wing, fuselage, vertical and horizontal stabilizer, ailerons, elevator, and rudder). Some of the major defects of the examined structure, classified by main assemblies, are presented in the further text.

- Wing was never in operational use; nevertheless the process of examination was detailed. NDT methods that have been applied here are: VT and ES for outer and inner surfaces and elements (skin, spars, ribs...), then ECT for bolts, joints and UT for fittings, rivets and axels inspection. - Location of the above mentioned defects is presented in the Fig.5.

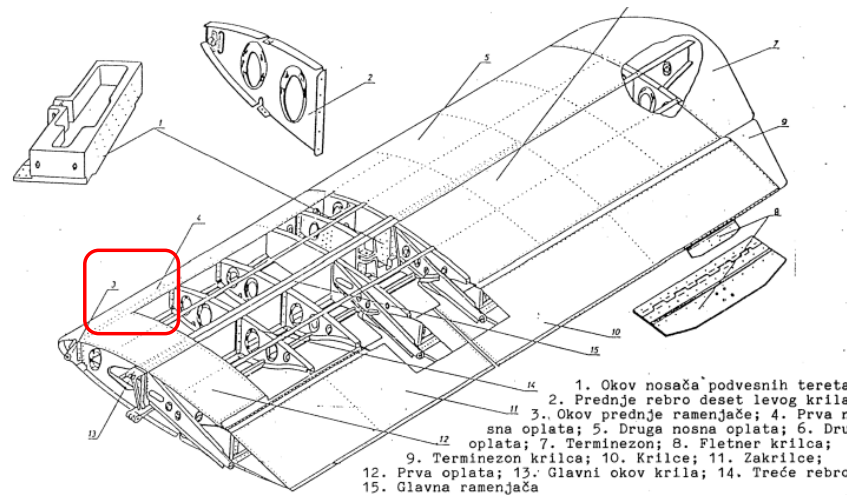

Figure 5. Left and right wing - damaged zone

The main defect was found in the bushing of the front spar left wing fitting (Fig.6 - right). Irregularities were found with UT and described as a lack of homogeneity. Also, some mechanical damages were found on the front spar right wing fitting (Fig.6 - left).
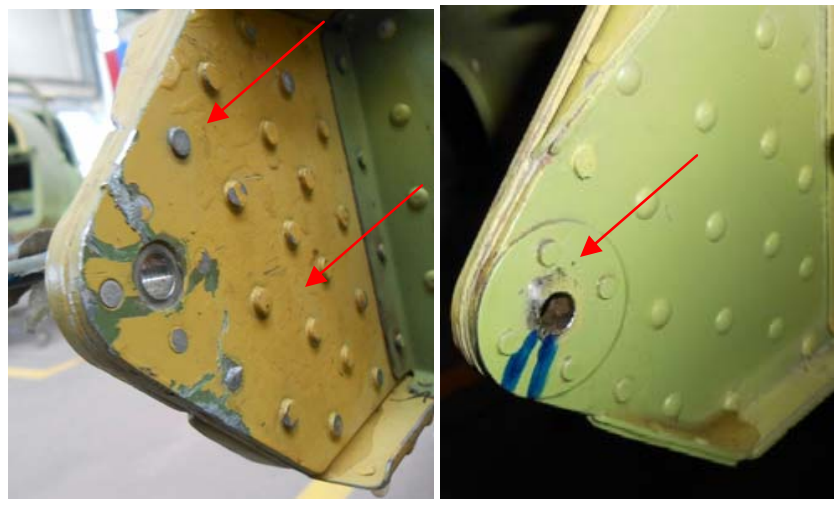

Figure 6. Left - left wing fitting mechanical defects Right - right wing bushing defect of homogeneity

- Vertical stabilizer was in storage and its inner structure was tested with ES and was healthy. Brackets were tested with UT and had no inner flaws, but some mechanical damages on the surface, at the lower bracket, were found. Location of the bracket and its irregularities is shown in Fig.7.

- Rudder was in operational use and had corrosion on the torsion tube. NDT methods confirmed that the damage is only on the surface, and with adequate treatment and protection it can easily be removed. Location of the torsion tube and its damage is presented in Fig.8.
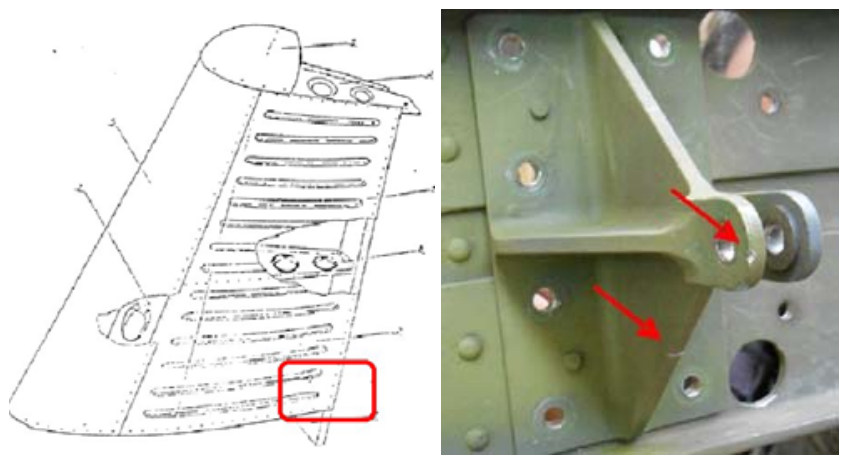

Figure 7. Left - vertical stabilizer - damaged zone Right - lower bracket, mechanical defects

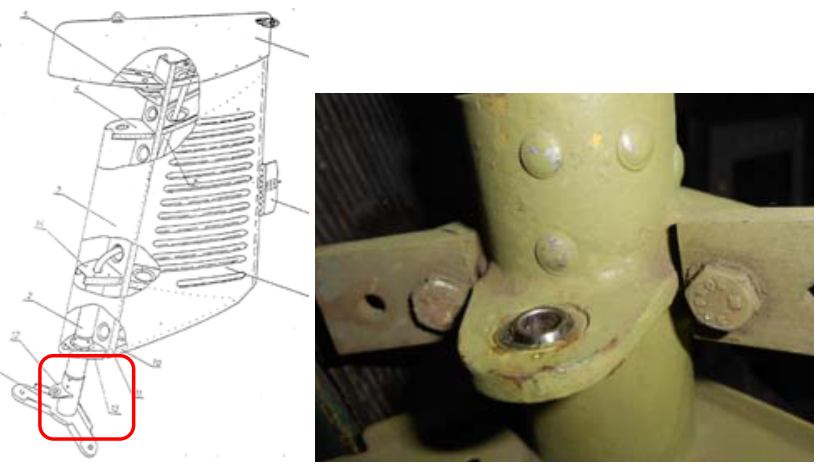

Figure 8. Left - rudder - damaged zone Right - torsion tube corrosion

- Horizontal stabilizer had traces of surface corrosion on the fittings that connect stabilizer with frame no.11 in the fuselage. Location of the fitting is presented in the Fig.9.

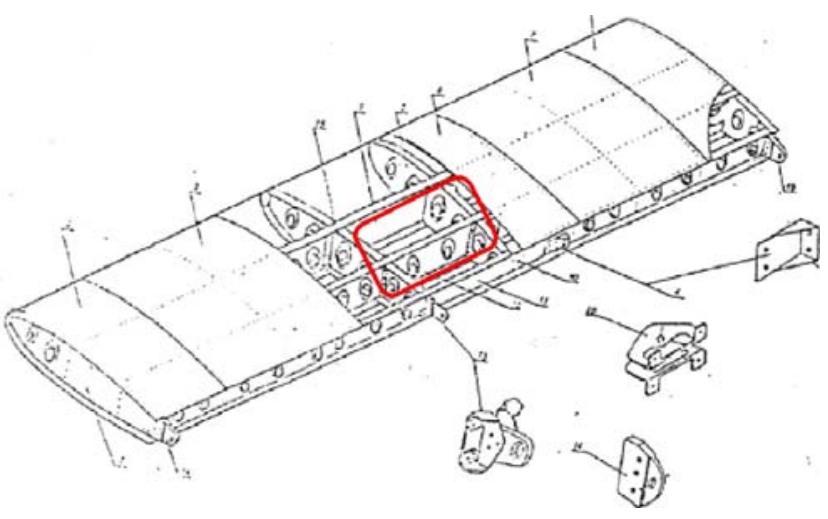

Figure 9. Horizontal stabilizer - damaged zone

NDT methods have confirmed that inner material of the fitting is without irregularities, and corrosion exists on a surface only. Damages of the fitting are shown in the Fig.10.

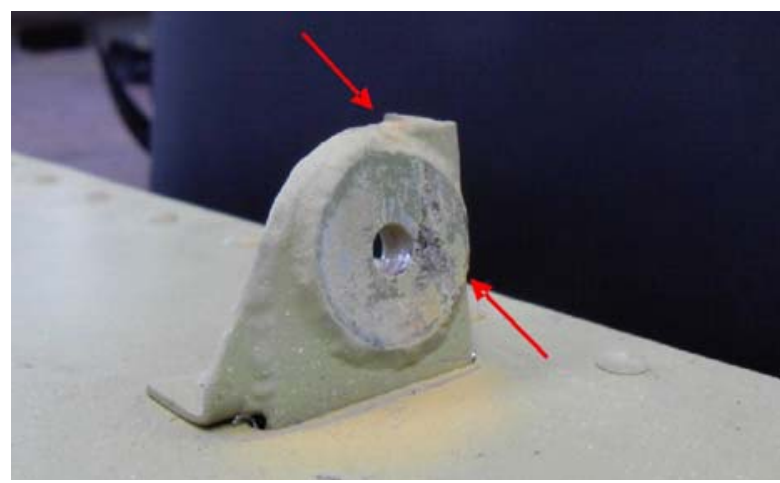

Figure 10. Corrosion of the horizontal stabilizer fitting 
- Elevator was in the operational use and had some mechanical deformations of the skin which was noticed by VT. Deformation of the upper skin near the outer rib appeared as a consequence of the wrong manipulation. Location of the deformed skin is presented in a Fig. 11 and mechanical damages in Fig. 12.

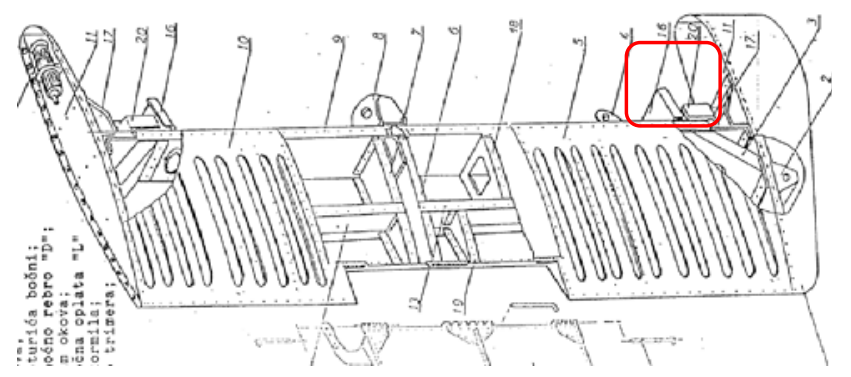

Figure 11. Horizontal stabilizer - damaged zone

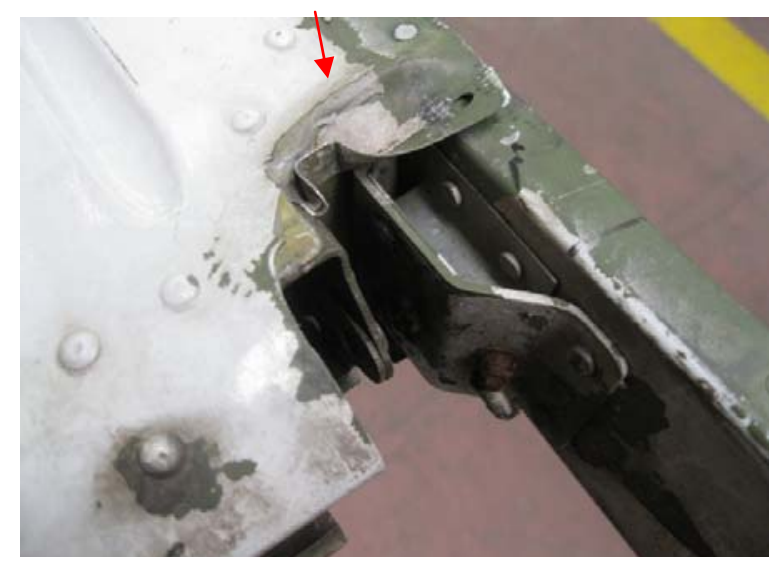

Figure 12. Deformed skin of the horizontal stabilizer

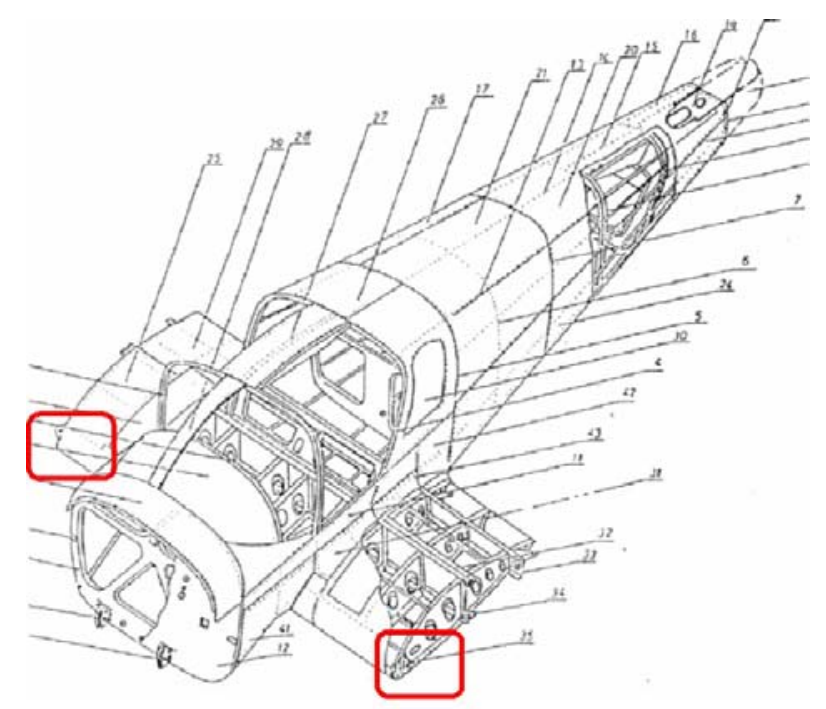

Figure 13. Fuselage - damaged zone

- Fuselage was in operational use and demanded more dedication and work, in order to examine the whole structure from the first to the last frame. The important information was that the greatest number of modifications were performed on the fuselage, and the most of the structure from the cockpit was changed during the process of examination. All NDT methods were used in order to locate defects of the material. Main tests were performed on the fittings that connect fuselage with wing and horizontal and vertical stabilizer and engine mount with the fuselage. They were placed on the first and eleventh frame. UT, ECT, PT confirmed that inner structure of the material (fittings, bushings, brackets, bolts, axels) was flawless. There were some traces of corrosion on the first frame fittings, but it was easily removed. Mechanical damages that have been detected are presented in the next figures, with location in the Fig. 13 and mechanical irregularities on the left fitting and right front skin in Fig.14.

After inspection, the report has been written. It includes the results of examined structure and the requirements for the mandatory repairs. The experts have confirmed, after control inspection of the structure, that all the necessary repairs are conducted in compliance with report requests. Consequently, life-cycle of the structure has been extended for 10 years.
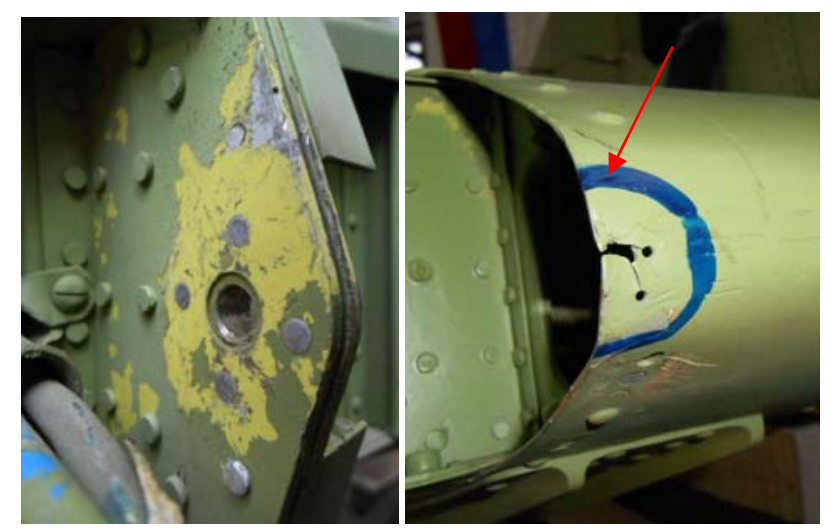

Figure 14. Left - mechanical damages of the fitting Right - right skin damages

\section{Prototype development}

New four-seater airplane was required to perform all of the training missions. It can be used for reconnaissance, photoshooting and other operations, depending on equipment. One special advantage of this aircraft version, equipped with advanced digital displays, is that it can be used for initial training of several trainees, reducing considerably the cost of the training

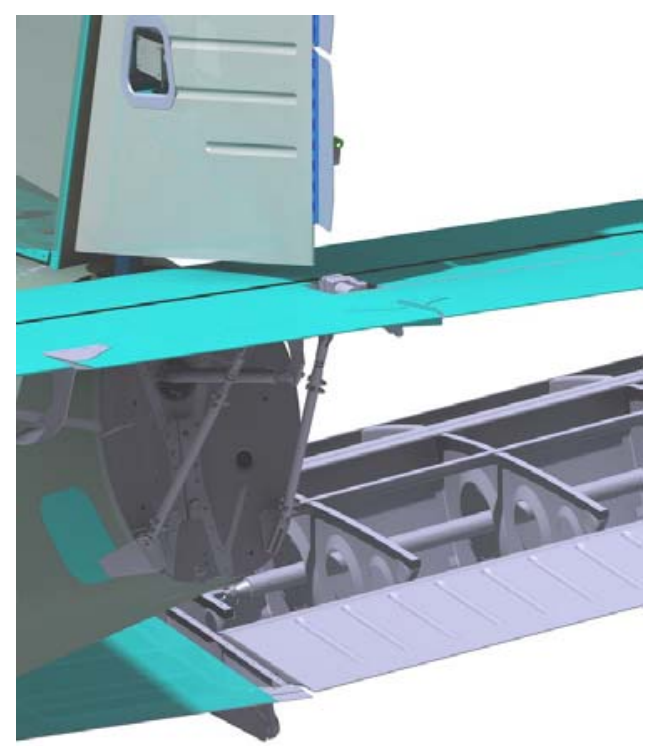

Figure 15. Unchanged structure of Sova aircraft

Whole metal structure Utva 75 with a side-by-side seating configuration, is a basis of the new four-seater airplane Sova. At the same time, with extension of a structure life-cycle, the 
conversion project has been conducted. In a process of prototype development two main approaches can be mentioned: modification of the structure and revision and upgrade of the aircraft systems.

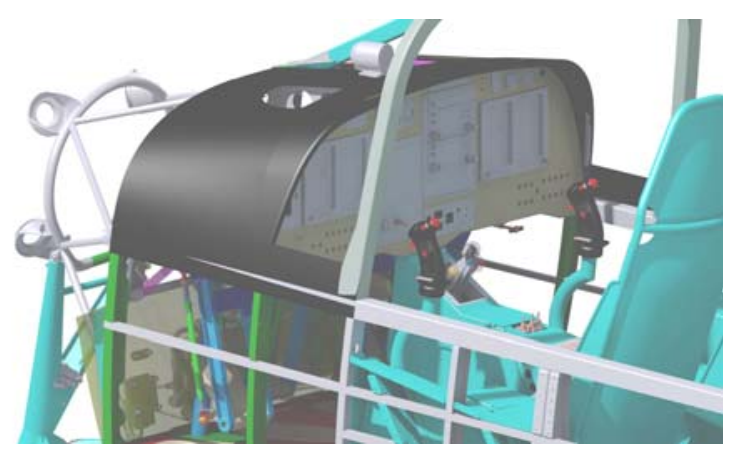

Figure 16. CAD model of redesigned cabin space

Structure revision consists of minimum changes on the wing and empennage (Fig.15), but central area of the fuselage is reinforced due to two additional passenger seats and enlarged cabin doors.

Main modification was performed in the cabin space (seats, instrument panels, controls, etc.). There is a new digital instrument panel, pilot sticks and engine controls (Fig.16); redesigned pilot seats area, with addition of central and side console which are also used as a support for pilot seats. Pilot seats can be set in six position, providing suitable accommodation for any pilot.

Second approach was an upgrade of the aircraft systems, making the aircraft concurrent on the market, with redesigned primary and secondary control system with electrical trim and flaps actuators. Pedals in the cabin area are redesigned and adjustable according to pilot's needs. There is a completely new fuel system, with the new boost pump and fuel selector with four positions (left, right, both tank and fourth position for fuel off). There is also a new hydraulic pipe line with the same non retractable landing gear as on Utva 75. Completely new ventilation system and electrical air condition unit was made.

Changes, including reinforced structure and mass increase, consequently led to revision in a propulsion. New engine has been integrated, Lycoming IO-390-A1 B6 (max power 210 $\mathrm{hp}$ ) paired with appropriate two blades Hartzell propeller. It improves aircraft maneuverability in comparison with former Utva 75. Engine mount was tested, and then slightly modified in accordance with the new engine (Fig.16).

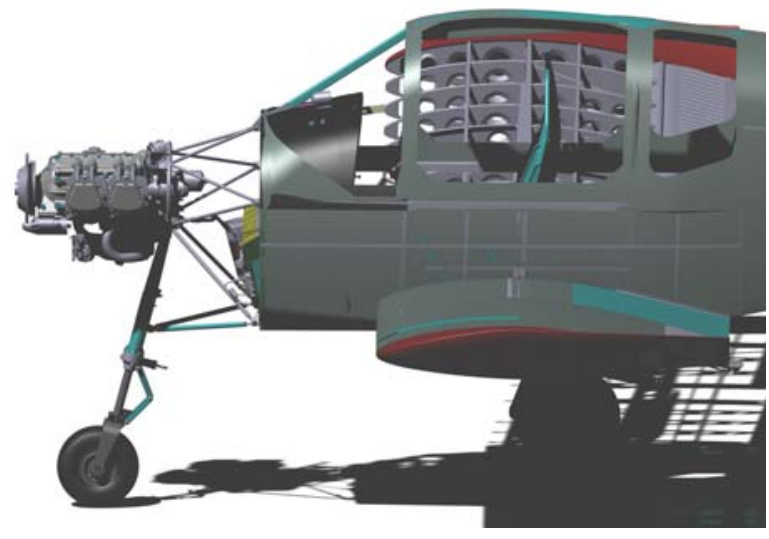

Figure 16. CAD model front Sova aircraft section

\section{Conclusion}

After inspection of the Utva 75 structure, life-cycle extension has been confirmed. Conversion, as a choice of money-time saving solution, has been performed on the existing structure. Project included redesign of the central fuselage part, with emphasis on the cabin area modification. New control and propulsion systems are integrated. Whole project is supported by modern design software (CATIA V5) (Fig.17).

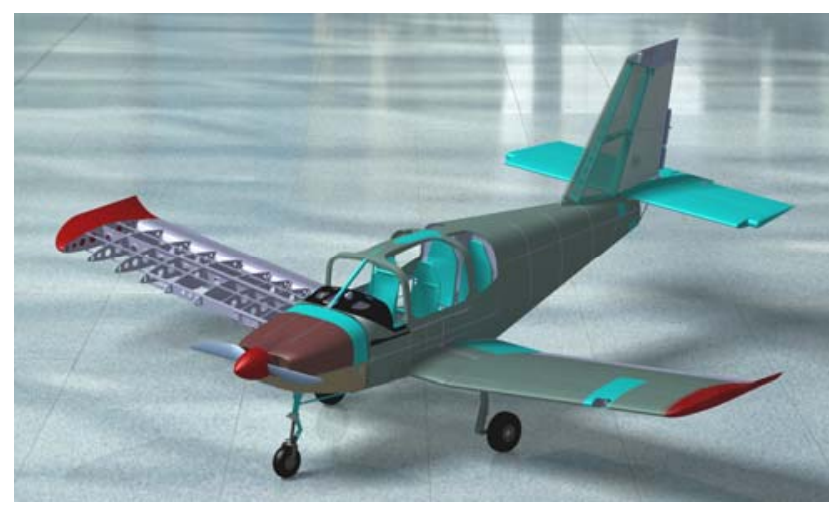

Figure 17. CAD model of Sova aircraft

Sova (Utva 75 A41M), as a conversion of Utva 75, with modification of cockpit area, controls, propulsion will result in a new CS 23 certification (Certification Specification for Normal, Utility, Acrobatic and Commuter Category Airplanes).

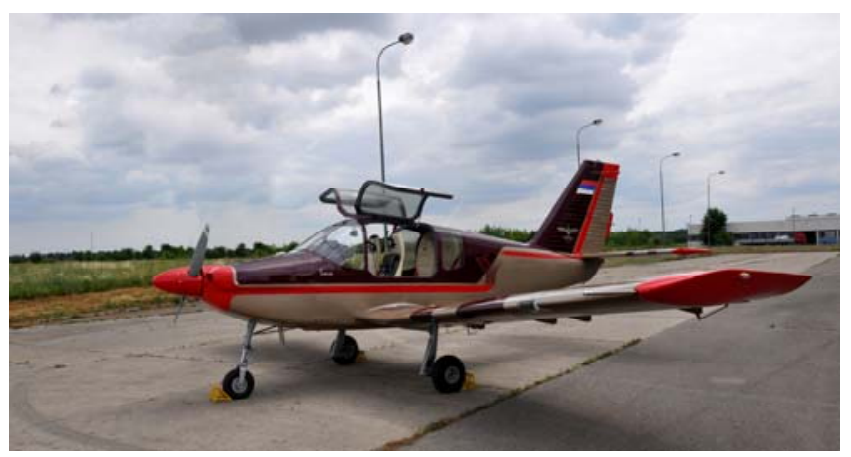

Figure 18. Sova - Technical demonstrator

Time and costs that have been used in a process of the development of a feasibility study, the designing modifications, producing elements, mounting, then integration of new the aircraft systems are considerably less than the design and production of a completely new aircraft. Not to mention, a confirmation of efficiency and maintainability of 40 years long operational use of the Utva 75, and the importance of that pieces of information collected in a process of development of the aircraft, make this conversion affordable solution.

\section{References}

[1] NIU,C.Y.: Michael, Airframe structural design, Hong Kong Conmilit Press LTD., Hong Kong, 1999.

[2] DIMITRI,N., MAVRIS,D., Delaurentis,A.: A probabilistic approach for examining aircraft concept feasibility and viability, Aircraft Design, June 2000, Vol.3, No.2, pp.79-101.

[3] LYLE Jr,J.W.: Converting A Citation Business Jet to a military trainer, Aircraft Design, March 1998,Vol.1, No.1, pp.51-60

[4] MILUTINOVIC,S.: Konstrukcija aviona, Beograd, 1970 
[5] ALLEN,R.: Aircraft conversions: specialist freighter conversions work expands, Aircraft Engineering and Aerospace Technology, ISSN 00022667, 2001, Vol.73, No.6.

[6] Boeing to convert five MD-11s to freighters, Aircraft Engineering and Aerospace Technology, ISSN 0002-2667, 2004, Vol.76, No.2.

[7] Three-bladed prop conversion for the Piper Comanche 260C, Aircraft Engineering and Aerospace Technology, ISSN 0002-2667, 2003, Vol.75, No.5.
[8] VASIC,Z., BLAŽIĆ,M., STEFANOVIĆ,V.: Reconstruction of aircraft structure with the aim of optimizing and extending aircraft life-cycle, $5^{\text {th }}$ International Scientific Conference on Defensive Technologies OTEH 2012, 18-19. September 2012, Belgrade, Serbia, ISBN 978-8681123-58-4, pp.182-186.

\title{
Razvoj prototipa "SOVA": produženje životnog ciklusa aviona
}

U cilju razvoja novog modela jednomotornog aviona sa četiri sedišta i fiksnim stajnim trapom, urađena je analiza strukture aviona UTVA 75 koja je korišćena kao osnova novog prototipa aviona SOVA. Elementi strukture aviona su ispitivani metodama bez razaranja (NDT). Ovaj rad opisuje stanje postojeće strukture aviona, a na osnovu dobijenih rezultata ispitivanja sugerišu se neophodne popravke i zamene određenih delova kako bi se produžio životni vek strukture i prilagodio eksploatacionim zahtevima novog modela aviona.

Ključne reči: elisni avion, laki avion, struktura letelice, metoda ispitivanja, ispitivanje bez razaranja, životni ciklus, produženje radnog veka.

\section{Разработка прототипа „СОВА“: продление жизненого цикла самолёта}

\begin{abstract}
С целью разработки новой модели одномоторного четырёхместного самолёта, с фиксированными шасси, был проведён анализ существующей структуры самолёта УТВА-75, которая была использована в качестве основы нового прототипа самолёта СОВА. Структурные элементы самолёта исследованы методом неразрушающего контроля (НК). Этот документ описывает состояние существующей структуры самолёта, а на основе полученных результатов испытаний рекомендуются необходмый ремонт а также и замена повреждённых частей, для того, чтобы продлить срок службы конструкции и адаптировать её к требованиям эксплуатации новой модели самолёта.

Ключевые слова: винтовый самолёт, сверхлёгкий самолёт, конструкция самолёта, метод тестирования, метод неразрушающего контроля, жизненный цикл, продление срока эксплуатации.
\end{abstract}

\section{Le développement du prototype "SOVA": prolongement de la durée de vie d'avion}

\begin{abstract}
Dans le but de développer un nouveau avion monopropulseur à quatre sièges et au train d'atterrissage fixe on a fait l'analyse de la structure de l'avion UTVA 75 qui a servi de base pour le nouveau prototype d'avion SOVA. Les éléments de la structure de cet avion ont été examinés par les méthodes sans destructions (NDT). Ce papier décrit l'état de la structure existante de l'avion et à la base des résultats d'essais on suggère les réparations nécessaires et le remplacement des pièces endommagées afin de prolonger la durée de vie de la structure et de l'adapter aux exigences d'exploitation du nouveau modèle d'avion.
\end{abstract}

Mots clés: avion à hélice, avion léger, structure d'aéronef, méthode d'essai, essai sans destruction, durée de vie, prolongement de duré de travail. 